\title{
Shikata Ga Nai: \\ Statelessness and Sacrifice for Japanese-American Volunteers During the Second World War
}

\author{
Kenzo E. Okazaki \\ Middlebury College
}

"Herd 'em up, pack'em off and give 'em the inside room in the badlands. Let 'em be pinched, hurt, hungry and dead up against it...let us have no patience with the enemy or with anyone whose veins carry his blood...personally, I hate the Japanese. And that goes for all of them."1

-Henry McLemore, Columnist, Hearst Newspapers

\section{Introduction}

Fundamental to the American experiment since its inception is the question of how a nation of immigrants can confront race and difference in ensuring the ability of its citizens to pursue a dignified life within it. Racism and discrimination have never been confined to presidents or to the public. The legal system has produced some of the most concerning racial injustices throughout the history of the United States. ${ }^{2}$ The supposed objectivity behind which these injustices are masked renders them all the more insidious.

Japanese Americans represent some of the most notable victims of legal racism in the form of their internment during the Second World War. The memory and legacy of this event has served as a motivation for "Japanese Americans to forge sympathetic connections with...new immigrant groups who are at risk of suffering the same racist mistreatment." ${ }^{3}$ In an amicus brief

\footnotetext{
${ }^{1}$ Henry McLemore, “This Is War! Stop Worrying About Hurting Jap Feelings," Seattle Times, January 30, 1942, accessed November 9, 2019, http://densho.org/wpcontent/uploads/2016/06/Documents_SPW.pdf.

${ }^{2}$ This kind of injustice is evident in the legal fiction of the enslaved as both people and property and the resultant three-fifths clause. Indeed, Malick W. Ghachem described how this clause issued from the absurd view of "the mixt' character of persons who were also property, things that were also persons." "The Slave's Two Bodies: The Life of an American Legal Fiction," William and Mary Quarterly 60, no. 4 (Oct. 2003): 810.

${ }^{3}$ Jane Naomi Iwamura, "Critical Faith: Japanese Americans and the Birth of a New Civil Religion," American Quarterly 59, no. 3 (Sep. 2007): 943.
} 
submitted to the Supreme Court in opposition to the President Trump's "Muslim ban," the Japanese American Citizens League (JACL) reiterated sentiment from their amicus brief in Hirabayashi v. United States writing that they "look[ed] to this Court, as the guardians of the liberties of all the people of the United States...to protect them from such discrimination as this...not for their sake alone, but also for the sake of every minority racial group in American life." 4 The JACL argued that the president's policy appealed to public fear of the "other" to justify extreme measures to ensure national security which was similarly apparent in the years leading up to internment. There are distinct dangers in this scramble for security with regard to the law and those subject to it. The JACL wrote later in their brief that, "the Government insists that this Court must accept its talismanic incantation of 'national security' and shirk its core responsibility to take a hard look at arbitrary, discriminatory, and harmful treatment of a disfavored group." Justice Sonia Sotomayor went so far as to write in her dissent of Trump v. Hawaii that in sanctioning a discriminatory travel ban "in the name of a superficial claim of national security, the Court redeploys the same dangerous logic underlying Korematsu and merely replaces one 'gravely wrong' decision with another." 6 This sense of déja-vu was made all the more tangible in the Government's recently announced plans to detain immigrants at Fort Sill, Oklahoma, a base once used as an internment camp for Japanese Americans. ${ }^{7}$ The imprisonment of over a hundred thousand Issei ("first-generation") and Nisei ("secondgeneration") Japanese immigrants on the basis of their ancestry lives on in American consciousness not only as the "defining moment...that both informs and haunts JapaneseAmerican identity...to this day," but also as a revelation regarding the nature of rights and resistance in times of crisis. ${ }^{8}$ The Supreme Court and surrounding legal discourse placed Japanese-American internment outside of legal jurisdiction. Those within the camps were thus condemned to a life lacking political qualification and juridical personhood. Faced with the dangers of this condition, interned Japanese Americans who served in the U.S. military consciously laid claim to the American political community through the sacrifice of their lives. These soldiers therefore performed a thoroughly political act of resistance rather than of pure patriotism.

\footnotetext{
${ }^{4}$ Brief for the Japanese American Citizens League as Amicus Curiae Supporting Respondents at Donald J. Trump, President of the United States v. International Refugee Assistance Project, No. 16-1436 (U.S. June 2, 2017) and at Donald J. Trump, President of the United States v. State of Hawaii, No. 16-1540 (U.S. June 26, 2017) [hereinafter Brief for the United States], 2.

${ }^{5}$ Brief for the Japanese American Citizens League as Amicus Curiae, 2.

${ }^{6}$ Trump v. Hawaii, 585 U. S. ___ (2018).

${ }^{7}$ Ben Fenwick, "'Stop Repeating History': Plan to Keep Migrant Children at Former Internment Camp Draws Outrage," The New York Times, June 22, 2019, accessed November 7, 2019, https://www.nytimes.com/2019/06/22/us/fort-sill-protests-japanese-internment.html; Fort Sill is also infamous for the detention of Native Americans, most notably Geronimo, during the "Indian Wars" of the late $19^{\text {th }}$ Century.

${ }^{8}$ Iwamura, "Critical Faith," 939.
} 


\section{A Failure to Protect}

Scholarly consensus in the wake of World War II has recognized the unconstitutionality of Executive Order 9066, which authorized the internment of Japanese Americans. Indeed, most scholars concur that "Korematsu is a tainted precedent, more reviled than respected." 9 The current Supreme Court has affirmed this sentiment. In the recent and highly contentious case of Trump v. Hawaii, Chief Justice Roberts wrote that "the forcible relocation of U. S. citizens to concentration camps, solely and explicitly on the basis of race, is objectively unlawful and outside the scope of Presidential authority." ${ }^{10}$ The defining work on this issue, the 1983 report of the Commission on Wartime Relocation and Internment of Civilians, offers some insight into the court's desire to condemn this ruling. The report concluded that military necessity did not justify the exclusion and detention of Japanese Americans. ${ }^{11}$ Instead, the "causes that shaped these decisions were race prejudice, war hysteria and a failure of political leadership." ${ }^{\prime 2}$ The 1942 report of Lt. General DeWitt, who both recommended and oversaw the removal of Japanese Americans from the West Coast, confirms the discriminatory premise of this order. He wrote simply: "the Japanese race is an enemy race."13 In his 1943 testimony before the House Naval Affairs Subcommittee to Investigate Congested Areas, he elaborated that "we must worry about the Japanese all the time until he is wiped off the map." ${ }^{14}$ In his dissent in Korematsu v. United States, Justice Frank Murphy cited General DeWitt's blatant racism to indicate that internment was the result of an "erroneous assumption of racial guilt rather than bona fide military necessity." " Justice Murphy went on to argue that DeWitt had cast suspicion over an entire racial group and undermined the principle of individual culpability, a key tenet of American jurisprudence. Korematsu, then, represented nothing less than the "legalization of racism."16 This landmark case set precedent which would not be overturned until 2018. ${ }^{17}$

Having established that Korematsu is nearly universally held to represent an affront to American jurisprudence, it is clear that the Supreme Court failed in its responsibility to protect the constitutional rights of Japanese Americans. This comes as no surprise to David Cole who

\footnotetext{
${ }^{9}$ Richard H. Fallon Jr. and Daniel J. Meltzer, "Habeas Corpus Jurisdiction, Substantive Rights, and the War on Terror," Harvard Law Review 120, no. 8 (June 2007): 2077.

${ }^{10}$ Trump v. Hawaii, 585 U.S. ___ (2018).

${ }^{11}$ Commission on Wartime Relocation and Internment of Civilians, Personal Justice Denied: Report of the Commission on Wartime Relocation and Internment of Civilians (Washington D.C.: Civil Liberties Public Education Fund, 1997), 459.

${ }^{12}$ Commission on Wartime Relocation and Internment of Civilians, Personal Justice Denied, 459.

${ }^{13}$ United States Department of War, United States Fourth Army, Final Report: Japanese Evacuation from the West Coast 1942 by John Lesesne DeWitt. U.S. Western Defense Command and Fourth Army, San Francisco, 1943.

${ }^{14}$ Cong. Rec. S1, 739-40 (April 13, 1943) (voluntary testimony of Lt. General DeWitt before the House Naval Affairs Subcommittee to Investigate Congested Areas) https://babel.hathitrust.org/cgi/pt?id=umn.31951d03671272h\&view=1up\&seq=5.

${ }^{15}$ Korematsu v. United States, 323 U. S. 214 (1944).

${ }^{16}$ Korematsu v. United States, 323 U. S. 214 (1944).

${ }^{17}$ Charlie Savage, "Korematsu, Notorious Supreme Court Ruling on Japanese Internment, Is Finally Tossed Out," The New York Times, June 26, 2018, accessed November 16, 2019, https://www.nytimes.com/2018/06/26/us/korematsu-supreme-court-ruling.html.
} 
holds as conventional wisdom that "courts are ineffective as guardians of liberty when the general public is clamoring for security." ${ }^{18}$ Re-examining the nature of legal decisions in times of emergency demonstrates, however, that this scholarly consensus falls short in its explanatory capacity and reveals the extra-legality of Japanese-American internment. Cole cites numerous causes of the court's inadequacy. Two of these, which are painfully clear in the case of JapaneseAmerican internment, not only indicate that Cole is correct in his thesis but substantiate an even larger claim: internment represented an event beyond the pale of legal-jurisdiction altogether. Cole writes that courts fare poorly in times of war as they cannot stand above the crisis because of their inability to access complete information. ${ }^{19}$ This informational deficit is evident in the suppression of evidence in Korematsu. In a 1941 report from the Office of Naval Intelligence, the Ringle Report for short, Lieutenant Commander Kenneth Ringle concluded that "the entire 'Japanese Problem' has been magnified out of its true proportion, largely because of the physical characteristics of the people." ${ }^{20} \mathrm{He}$ further emphasized the problematic racial nature of this issue by indicating that suspicion should not be held to a greater degree of those of Japanese descent than on Germans, Italians, and communists. ${ }^{21}$ As such, Ringle recommended that concerns about Japanese Americans should be handled case by case "and not on a racial basis." 22 The conclusions of this report seriously undermined the claim of military necessity advanced by the United States, especially considering the fact that descendants of other "enemy" groups were not similarly interned or suspected. ${ }^{23}$ The Solicitor General, however, withheld this report from the Supreme Court during its deliberations on two landmark cases regarding internment, Hirabayashi v. United States and Korematsu v. United States. ${ }^{24}$ In 2011, the office of the Solicitor General of the United States released a statement which confessed to the grave wrong done by their office with regard to the Ringle Report. The acting Solicitor General at the time, Neal Katyal, confirmed that "by the time the cases of Gordon Hirabayashi and Fred Korematsu reached the Supreme Court, the Solicitor General had learned of a key intelligence report that undermined the rationale behind the internment." 25 The Solicitor General in question, Charles Fahy, justified his dishonesty with the court on largely racial grounds. Indeed, in defending his

\footnotetext{
${ }^{18}$ David Cole, "Judging the Next Emergency: Judicial Review and Individual Rights in Times of Crisis," The Michigan Law Review Association 101, no. 8 (Aug. 2003): 2568.

${ }^{19}$ Cole, "Judging the Next Emergency," 2570.

${ }^{20}$ United States Department of the Navy, Japanese Question, Report On by Kenneth D. Ringle. Lieutenant Commander United States Navy, Los Angeles, 1941.

${ }^{21}$ United States Department of the Navy, Japanese Question.

${ }^{22}$ United States Department of the Navy, Japanese Question.

${ }^{23}$ Though recent scholarship has recognized that some German and Italian Americans were also interned, the "omission of the...two groups in understandable because the wholesale relocation of Japanese-Americans - the majority, 70,000, being American-born - was the more egregious violation." "When Italian Americans Were 'Enemy Aliens,"” Rose D. Scherinni, in Una Storia Segreta: The Secret History of Italian American Evacuation and Interment during World War II, ed. Lawrence DiStasi (Berkeley: Heyday Books, 2001), 27.

${ }^{24}$ Neal Katyal, "Confession of Error: The Solicitor General's Mistakes During the JapaneseAmerican Internment Cases" [blog], United States Department of Justice, May 20, 2011, accessed November 7, 2019, https://www.justice.gov/archives/opa/blog/confession-error-solicitor-generalsmistakes-during-japanese-americaninternment-cases.

${ }^{25}$ Katyal, "Confession of Error."
} 
suppression of evidence, Fahy referenced the disloyalty and racial solidarity of Japanese Americans. ${ }^{26}$ This suppression was not inconsequential as it was later employed to overturn Korematsu's conviction in district court. ${ }^{27}$

More concerning in understanding the failure of the Supreme Court in times of crisis, in that it is independent of the facts of the case itself, is the tendency of the court to rule in favor of the government amid concerns regarding legitimacy. Indeed, "courts must worry that if they rule against the government on a matter of national security, they may face a potential test of their credibility and legitimacy." ${ }^{28}$ In other words, should the president disagree with their decision, they may refuse to enforce it and reveal the impotence of the court. Worcester v. Georgia is one ruling that illustrates this danger. In this case, the court ruled that the Cherokee nation was a dependent sovereign state protected from interference by citizens of Georgia. ${ }^{29}$ The court could do no more than watch, however, as President Andrew Jackson flaunted the ruling and allowed the removal of Cherokees to proceed. ${ }^{30}$ The snub of their legitimacy at the hands of the president was well summarized by President Jackson himself who reportedly remarked: "John Marshall made the decision; let him enforce it." 31 As he evaluated the Korematsu case, this concern was at the forefront of Justice Jackson's consciousness. He worried that should the court rule against the government, "the War Relocation Authority might refuse to comply with the courts' orders." 32 His dissenting opinion, then, represented a great risk as he admitted in a 1951 lecture. He confessed: "my view, if followed, would come close to a suspension of the writ of habeas corpus or recognition of a state of martial law at the time and place found proper for military control.",33

The question of legitimacy was not lost on President Roosevelt who discussed plans to defy a ruling against the order with Justice Jackson. ${ }^{34}$ According to Justice Jackson, Roosevelt had admitted "that outright defiance of the court was possible." ${ }^{35}$ Roosevelt did not merely contemplate this possibility but had prepared to execute it in the past. During a 1935 case which challenged his executive order to abandon the gold standard, Roosevelt drafted a radio speech which reads:

To stand idly by and to permit the decision of the Supreme Court to be carried through to its logical, inescapable conclusion would so imperil the economic and political security of

\footnotetext{
${ }^{26}$ Katyal, "Confession of Error."

${ }^{27}$ Korematsu v. United States, 582 F. Supp. 1406 (N.D. Cal. 1984).

${ }^{28}$ Cole, "Judging the Next Emergency," 2571.

${ }^{29}$ Worcester v. Georgia, 31 U.S. 515, 520 (1832).

${ }^{30}$ Marion L. Starkey, The Cherokee Nation (New York: Alfred A. Knopf, 1946), 184.

${ }^{31}$ Starkey, The Cherokee Nation, 184.

${ }^{32}$ Dennis J. Hutchinson, "'The Achilles Heel' of the Constitution: Justice Jackson and the Japanese Exclusion Cases," The Supreme Court Review 2002, (2002): 489.

${ }^{33}$ Robert H. Jackson, "Wartime Security and Liberty Under Law” (2007 James McCormick Mitchell Lecture, delivered at Buffalo Law School, Buffalo, NY, May 9, 1951).

${ }^{34}$ Hutchinson, "“The Achilles Heel' of the Constitution," 489.

${ }^{35}$ Robert H. Jackson, interview by Harlan B. Phillips, 1952, VI, Columbia University Oral History Project, Columbia University, New York City, NY.
} 
this nation that the legislative and executive officers of the Government look beyond the narrow letter of contractual obligations, so that they may sustain the substance. ${ }^{36}$

The threat of Presidential defiance thus loomed over the court as it put together its majority opinion. The most vehement critic of Justice Jackson's position was Justice Frankfurter who was careful to revise Justice Black's first draft of the Korematsu decision in a way that ensured "judicial deference." ${ }^{37}$ Cole and other scholars are thus correct in understanding that courts are ineffective when confronted with military emergency.

These influences which led the court to produce such an abhorrent ruling in Korematsu, however, amounted to more than a failure in their stewardship of liberty. The shortcomings of the judicial branch culminated, in this case, in an expulsion from the American political community by means of rendering Japanese American internment extra-legal. An analysis of the opinions of the court, concurrences, and dissents in both Hirabayashi and Korematsu reveals the unique orientation of the internment camp. Perhaps wishing to invoke Cicero's famous statement, "when arms speak the laws are silent" (silent enim leges inter arma), Justice Frank Murphy wrote in his concurring opinion in the unanimously decided Hirabayashi that the mere existence of a state of war does not entail the suspension of constitutional rights. ${ }^{38} \mathrm{He}$ went on, however, to write in concurrence that because of the "urgent necessity of taking prompt and effective action... against the risk of sabotage and espionage, the military authorities should not be required to conform to standards of regulatory action appropriate to normal times." 39 Finally, he briefly noted that "modern war does not always wait for the observance of procedural requirements." "40 Justice William Douglas similarly wrote that the judicial branch "cannot sit in judgment on the military requirements of that hour." ${ }^{41}$ Here, Justice Douglas explicitly recognized that the court could or would not render judgment on such issues. In this refusal, Justice Douglas placed the exclusion orders made by the military beyond the reach of legal judgment.

Turning to the case of Korematsu, Justice Felix Frankfurter concurred with the court writing that to describe "a military order that expresses an allowable judgment of war needs...as 'an unconstitutional order' is to suffuse a part of the constitution with an atmosphere of unconstitutionality." 42 The logical conclusion of Justice Frankfurter's reasoning is that the suspension of law is an element integral to the Constitution itself. In his dissent of the opinion rendered by the court in Korematsu, Justice Robert Jackson found the detention of Japanese Americans to be unconstitutional and racist, yet wrote in conclusion that he did "not suggest that

\footnotetext{
${ }^{36}$ Arthur M. Schlesinger, Jr., The Politics of Upheaval, vol. 3 of The Age of Roosevelt (Boston: Houghton Mifflin, 1960), 258.

${ }^{37}$ Peter Irons, Justice at War (Oxford: Oxford University Press, 1983), 332.

${ }^{38}$ Cicero, Pro Milone, trans. N.H. Watts (Cambridge: Harvard University Press, 1953), 17; Hirabayashi v. United States, 320 U.S. 81 (1943).

${ }^{39}$ Hirabayashi v. United States, 320 U.S. 81 (1943).

${ }^{40}$ Ibid.

41 Ibid.

${ }^{42}$ Korematsu v. United States, 323 U. S. 214 (1944).
} 
the courts should have attempted to interfere with the Army in carrying out its task." 43 Thus, in both Hirabayashi and Korematsu, the Justices of the Supreme Court either recognized the suspension of law as integral to times of war or that the Judicial branch could or would not interfere with the military even in the case of violations of constitutional rights. In both cases, the Supreme Court therefore affirmed that Japanese-American internment fell outside of the jurisdiction of the law altogether. So much for Justice Murphy's reply to Cicero.

The Supreme Court was not, however, solely responsible for this expulsion from legal jurisdiction. Sarah Ludington, a law professor at Campbell University, draws attention to the surprising phenomenon that "few law professors commented critically-or even uncritically-about the government's domestic policies during the war" of which Japanese-American internment represented one of the most controversial. ${ }^{44}$ Despite the unmistakable unconstitutionality of the program, academics, much like the court, experienced pressures which discouraged them from facilitating legal discourse surrounding it. The government employed many academics during the war and therefore economically hindered their desire to decry government policy. ${ }^{45}$ Additionally, "academics - like many Americans - may have been willing to turn a blind eye to civil rights abuses...in the interests of winning the war." 46 Thus, in the face of economic pressure and wartime hysteria, the legal academy was either unmotivated or incapable of defending the rights of Japanese Americans. This striking failure is no small issue. Indeed, by failing to criticize the policy, academics implicitly conceded that internment had no place in the realm of legal discussion. It would be incorrect to claim, however, that no academics spoke out. Ludington specifically cites a few cases where professors from law schools such as Yale, Harvard, and William and Mary criticized government policy under the protection of their "robust culture of academic freedom." ${ }^{47}$ It is unfortunate and alarming, though, that these professors were merely an exception to an otherwise disturbing rule.

\section{Rightlessness and the Internment Camp}

Internment's orientation outside of legal jurisdiction placed those within the camps in alarming danger with the loss of their juridical person. Juridical personhood "comes into being when political authority towards persons is expressed through an institutional order that bears attributes of stability such as predictability, intelligibility, and contestability." 48 The very nature of the camp was an essential component in depriving Japanese Americans of their juridical person. Indeed, Arendt contended that the loss of the juridical person was only completed "by

\footnotetext{
43 Ibid.

${ }^{44}$ Sarah H. Ludington, "The Dogs that Did Not Bark: The Silence of the Legal Academy During World War II," Journal of Legal Education 60, no. 3 (February 2011): 398.

${ }^{45}$ Ludington, "The Dogs that Did Not Bark," 404.

46 Ibid, 413.

${ }^{47}$ Ibid, 430.

${ }^{48}$ Kristen Rundle, "Legal Subjects and Juridical Persons: Developing Public Legal Theory through Fuller and Arendt," Netherlands Journal of Legal Philosophy 3, (2014): 228.
} 
placing the concentration camp outside the normal penal system, and by selecting its inmates outside the normal judicial procedure." 49 Rights are the essential elements which protect citizens in normal judicial proceedings in that they represent the conditions under which political authority is expressed. The destruction of the juridical person is thus identical with being without rights or, as Hannah Arendt described this condition, "rightlessness." It is clear that the court's affirmation of the suspension of law which internment entailed licensed the deprival of the most basic of constitutional rights. ${ }^{50}$ According to the Commission on Wartime Relocation and Internment of Civilians, those imprisoned in the camps quickly learned that "Constitutional rights were not an individual and personal guarantee if one were an American of Japanese ancestry." 51 This claim is more than one of inequality or deprivation. Arendt wrote that the plight of the rightless person "is not that they are not equal before the law, but that no law exists for them." $" 52$ This condition is embodied in the concept of citizenship insofar as it represents, for Arendt, the right to have rights. ${ }^{53}$ This is an exact parallel to the experience of interned Japanese Americans. Though the "government never formally stripped Japanese Americans of their citizenship...it in effect...nullified their citizenship." 54 Victor Izui, a volunteer from camp in Minidoka, Idaho, was keenly aware of this condition as he scoffed at a question about whether he felt American. He retorted simply: "how could you feel American? They took away your citizenship!"55

\footnotetext{
${ }^{49}$ Arendt, The Origins of Totalitarianism, 447. Though this essay has refrained from the use of the term "concentration camp," it is important to note that in his dissent in Korematsu v. United States, Justice Roberts describes the term "internment camp" as merely a euphemism for concentration camps. Though Justice Black admonishes the use of this descriptor with "all the ugly connotations that term implies," it is clear that these camps operated outside of normal judicial procedures and are equally reflective of Arendt's argument. Korematsu v. United States, 323 U. S. 214 (1944).

${ }^{50}$ Scholars have contended that the specific rights which the court rendered inapplicable in this case included: freedom of religion, freedom of speech, freedom of press, right to assemble, freedom from unreasonable search and seizures, right to an indictment or to be informed of the charges, right to life, liberty, and property, right to be confronted by accusatory witnesses, right to call favorable witnesses, right to legal counsel, right to a speedy and public trial, right to reasonable bail, freedom from cruel and unusual punishment, right to vote, right to habeas corpus, freedom from bills of attainder and ex post facto laws, rights against involuntary servitude, and right to equal protection under the laws. The Japanese -American Internment during WWII: A Discussion of Civil Liberties Then and Now, LegiSchool Project (Sacramento: Senate Publications, 2000), 30-34; it should also be noted that the internment camps were not merely a place of theoretical suffering, indeed, internment camps in Alaska produced mortality rates as high as $25 \%$ "Forced to Leave: WWII Detention of Alaskan Japanese Americans and Aleuts" in University of Alaska Museum, Mary Fenno, ed. Dean Kohlhoff and Terry P. Dickey (Fairbanks: University of Alaska Museum, 1997): 5.

${ }^{51}$ Commission on Wartime Relocation and Internment of Civilians, Personal Justice Denied, 299.

${ }^{52}$ Hannah Arendt, "The Perplexities of the Rights of Man," in Biopolitics: A Reader, ed. Timothy Campbell and Adam Sitze (Durham: Duke University Press, 2013), 88.

${ }^{53}$ Arendt, The Origins of Totalitarianism, 296.

${ }^{54}$ Mae M. Ngai, Impossible Subjects: Illegal Aliens and the Making of Modern America (Princeton: Princeton University Press, 2004), 175.

${ }^{55}$ Victor Izui, interview by Ian Kowata, April 29, 2000, Tape 2, Hanashi Oral History Archives, Go For Broke National Education Center, Chicago, IL, http://www.goforbroke.org/learn/archives/oral_histories_videos.php?clip=11402.
} 
What, then, is the precise meaning of this exile from political existence? Aristotle famously wrote that "man is by nature a political animal." ${ }^{56}$ Humans, for Aristotle, are animals with the capacity to organize themselves politically, and this type of organization is the end which separates man from all other animals, with whom he otherwise, on a biological basis, shares much in common. ${ }^{57}$ In the absence of a political community, then, individuals are left in a mere biological state. Though the deprival of constitutional rights is egregious in itself, the dangers of this state of being bereft of rights and extra-legal orientation produced an even greater danger as "the first essential step on the road to total domination is to kill the juridical person in man." 58 Arendt argued that that her thesis was at work in Nazi Germany, where Jewish individuals were deprived of any legal protection and, in short, "a condition of complete rightlessness was created before the right to live was challenged." ${ }^{, 59}$ Interned Japanese Americans were reduced to a life unqualified by the ability to possess legal or political rights and thus placed in alarming danger.

It would seem that this return to life stripped of its political qualification is the precise case in which one may claim the protections of human rights, yet this was not possible. Again, Arendt's work offers a useful tool of analysis and forecloses the possibility of seeking protection in anything but a political community. She wrote that in the absence of rights accorded by citizenship, people attempt to lay claim to their inborn rights, yet these rights are in natural opposition to civilization and are thus immediately suspect. ${ }^{60}$ While these inborn rights are based on unchanging principles of humanity, civilization is based on the principle of equality which is necessarily not inherent. Indeed, "we are not born equal; we become equal as members of a group on the strength of our decision to guarantee ourselves mutually equal rights." ${ }^{61}$ Izui confronted this reality as he realized that "[the Constitution] didn't mean anything. It was just a piece of paper."62 Izui recognized that the Constitution carried little force for Japanese Americans who had been expelled as subjects of this document. Though the Constitution and the rights which it establishes were intended by the framers to represent "certain unalienable Rights," as described by the Declaration of Independence, these supposedly inborn rights immediately lost force with the exile of Japanese Americans from the community which would guarantee them. ${ }^{63}$ Indeed, in her analysis of the development of human rights, Arendt wrote that "the moment human beings lacked their own government...no authority was left to protect them and no institution was willing to guarantee them." ${ }^{64}$ The term "inborn rights," is, therefore, an

\footnotetext{
${ }^{56}$ Aristotle, Politics, trans. W.D. Ross, in The Basic Works of Aristotle, ed. Richard McKeon (New York: The Modern Library, 2001), 1129.

${ }^{57}$ Giorgio Agamben, "Introduction to Homo Sacer: Sovereign Power and Bare Life," in Biopolitics: A Reader, ed. Timothy Campbell and Adam Sitze (Durham: Duke University Press, 2013), 135.

${ }^{58}$ Hannah Arendt, The Origins of Totalitarianism (San Diego: Harcourt Brace Jovanovich, 1973), 447.

${ }^{59}$ Arendt, The Origins of Totalitarianism, 296.

${ }^{60}$ Ibid, 301.

${ }^{61}$ Ibid, 301.

${ }^{62}$ Izui, interview.

${ }^{63}$ Thomas Jefferson, "The Declaration of Independence," Historic American Documents (1776), accessed December 13, 2019, https://etc.usf.edu/lit2go/133/historic-americandocuments/4957/the-declaration-of-independence/.

${ }^{64}$ Arendt, "The Perplexities of the Rights of Man," 82.
} 
oxymoron. Furthermore, claiming these rights gives rise to another unique danger. Arendt argues that this opposition between the claim to natural rights and equality through organization remind states "of the limitations of human activity." 65

For this reason, Arendt claims, "highly developed political communities, such as the ancient city-states or modern nation-states, so often insist on ethnic homogeneity is that they hope to eliminate as far as possible those natural and always present differences and differentiation" which represent the areas which man cannot change and which they tend to destroy in forms such as ethnic cleansing. ${ }^{66}$ The interned were thus confronted with the necessity of regaining their place in the American community in the absence of their juridical person.

The internment diary of Hatsuye Egami offers a material illustration of this abstract claim in representing the human experience of a life deprived of its juridical person. Egami was born in Tokyo in 1902 and immigrated to the United States in $1921 .{ }^{67}$ Besides this and limited information about Egami's family, little is known about her life. ${ }^{68}$ Her diary begins on May 12, 1942, immediately before she is to be relocated to the Tulare Assembly Center. As she reflects on the whirlwind of relocation, she laments that "since yesterday, we Pasadena Japanese have ceased to be human beings - we are now simply numbers or things. We are no longer 'Egamis' but the number 23324." "69 The Egamis thus immediately recognize that the loss of their rights is tantamount to a lack of humanity itself. It is this feeling which Arendt explains as she considers human rights. Paradoxically, though these inborn rights are meant to apply precisely in the case where a person lacks a political community willing to ensure legal rights and therefore has nothing to claim but his or her humanity, "the opposite is the case... a man who is nothing but a man has lost the very qualities which make it possible for other people to treat him as a fellowman." ${ }^{70}$ Egami continues her reflection in describing her hope for the future despite her realization of their expulsion from the body politic. She wrote: "it may be that in a naked life there is poetry and truth. I think that from this bare life we can weave something creative and interesting. The person that can do that is one who is really intelligent and wise." $" 71$

Egami's words prove prophetic as it is precisely through the body itself that Japanese Americans crafted lives of dignity and resistance in the face of such ominous conditions. The nullification of citizenship for Japanese Americans which placed them in such alarming danger also posed a challenge to their resistance. They had not lost their rights, but the right to possess them in the first place. Thus, challenges based on a claim of rights could only fail. Their natural life without political qualification also possessed no rights in itself. Their only hope, then, was to

\footnotetext{
${ }^{65}$ Arendt, The Origins of Totalitariansim, 301.

${ }^{66}$ Ibid, 301.

${ }^{67}$ Claire Gorfinkel, introduction to The Evacuation Diary of Hatsuye Egami, by Hatsuye Egami, trans. James Sakoda (Pasadena: Intentional Productions, 1996), 14.

${ }^{68}$ Gorfinkel, introduction to The Evacuation Diary, 14.

${ }^{69}$ Hatsuye Egami, The Evacuation Diary of Hatsuye Egami, trans. James Sakoda (Pasadena: Intentional Publications, 1996), 20.

${ }^{70}$ Arendt, "The Perplexities of the Rights of Man," 93.

${ }^{71}$ Egami, The Evacuation Diary, 27-28.
} 
regain that right which precluded them from the others, their membership in the American political community, through the sacrifice of the bare corpus.

\section{Volunteering as a Political Act}

Though some volunteers chose to sacrifice their lives, others refused to serve on the basis of the violation of their rights. The position of the JACL at the time was that Japanese Americans should join the U.S. army in order to prove their loyalty. ${ }^{72}$ The League went so far as to suggest a suicide battalion of Japanese American soldiers who would be sent to die in impossible missions. ${ }^{73}$ There were, however, a considerable number of internees who refused to serve on the grounds that they had been denied their constitutional rights. These "no-no boys" claimed that they could not be expected to perform their obligations as citizens when their citizenship had been nullified. ${ }^{74}$ For them, it was "absurd to ask any interned individual to defend American democracy from behind barbed wire." "75 A great deal of conflict erupted between these groups within the camps. Robert Ichikawa, a volunteer from the Amache, Colorado, internment camp recalled: "all the no-no boys, you know they called us all kinds of names, they called us dogs, inu." $" 76$

In some cases, the tension between the two groups was so extreme that it resulted in violence. Those Japanese Americans educated in Japan were commonly referred to as "kibei" and were generally opposed to volunteering to serve. Masaru Ishida, another volunteer from Topaz, Utah, recalled: "We had some kibeis, well they were mean you know?"77 He goes on to tell a story about his friend saying: "He nearly got killed because, you know, he said 'volunteer, volunteer!",78 This was not an isolated event in Topaz. Ishida recalled that he had to help another friend run away because "they were gonna kill him too because he was pro-serving the country."79 This opposition ran so deeply that it often affected the families of volunteers as well. Izui learned after the war that once he had left for training, some parents of the no-no boys "came

\footnotetext{
72 Arthur A. Hansen, “The 1944 Nisei Draft at Heart Mountain, Wyoming: Its Relationship to the Historical Representation of the World War II Japanese American Evacuation," OAH Magazine of History 10, no. 4 (Summer, 1996): 52.

${ }^{73}$ Paul R. Spickard, “The Nisei Assume Power: The Japanese Citizens League 1941-1942,” Pacific Historical Review 52, no. 2 (May 1983): 164.

${ }^{74}$ Holly Allen, "The Citizen-Soldier and the Citizen-Internee: Fraternity, Race, and American Nationhood, $1942-$ 46," in Forgotten Men and Fallen Women: The Cultural Politics of New Deal Narratives (Ithaca: Cornell University Press, 2015), 184.

75 Allen, "The Citizen-Soldier and the Citizen-Internee," 187.

${ }^{76}$ Robert Ichikawa, interview by Russell Nakaishi, February 25, 2001, Tape 2, Hanashi Oral History Archives, Go For Broke National Education Center, Los Angeles, CA, http://www.goforbroke.org/learn/archives/oral_histories_videos.php?clip=15502.

${ }_{77}$ Masaru Ishida, interview by Robert Horsting, June 29, 2002, Tape 2, Masaru Ishida Oral History Interview, Japanese American History Collective, Chicago, IL,

http://www.goforbroke.org/learn/archives/oral_histories_videos.php?clip=29102.

${ }^{78}$ Ishida, interview.

${ }^{79}$ Ibid.
} 
to [his] mother and gave her a real bad time." ${ }^{80}$ The resentment flowed both ways. Kaihara, remembers that "at first I resented [no-no boys] being that way, but after giving it a great deal of thought...I might have done the same thing." 81 Kaihara's newfound sympathy is shared by revisionist historians who have come to define each action as "complementary species of praiseworthy Americanism" in order to combat the no-no boys' widespread ostracism from not only American society but also from that of the Japanese-American community. ${ }^{82}$ Despite this claim of respect for each position, there remains an opposition between these two responses insofar as scholars often hold that though those who refused to serve made a political statement of resistance, those who volunteered were apolitical and concerned only with patriotic duty.

Some scholars have gone so far as to label the apparent pure patriotism of volunteers from internment camps as a "'blind obedience' response to injustice." ${ }^{83}$ At the surface level, the oral histories of once interned veterans seem to support this claim. Ishida remembers his mother telling him to serve in a simple imperative: "You gotta be patriotic." ${ }^{44}$ Similarly, though Izui did not feel initially inclined to volunteer, it was his mother who convinced him to join. Izui remembers that "she urged loyalty, unstinting loyalty to my country, even if she was wrong in interning us." 85 This sentiment was echoed by Jimmy Konno who said as he described his reasons for serving rather than resisting: "If you're gonna live in this country, you gotta do something, and if you wanna resist I won't go against ya, that's your decision." 86

Further examination reveals, however, that the loyalty of these volunteers was far from blind. Stanley Hayami, a volunteer from the Heart Mountain internment camp, wrote: "Do I think it was constitutional? No, I do not. We did not go through due process of law...Do I think racial prejudice was involved? Yes." ${ }^{87}$ Izui recalled feeling betrayed by the promises of the American experiment saying: "all that stuff that they taught us in school, what the heck does that mean? What a sham."88 Yasunori Deguchi, a volunteer from Hawaii, expressed a similar sentiment when he learned about internment from the mainland volunteers. He was astounded that "the country we were supposed to have gotten the right information from school

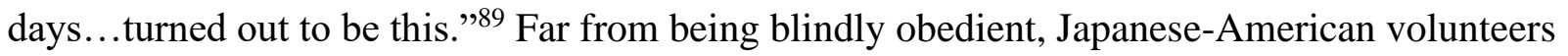

\footnotetext{
${ }^{80}$ Izui, interview.

${ }^{81}$ Thomas Kaihara, interview by Richard Hawkins, June 27, 2002, Tape 3, Hanashi Oral History Archives, Go For Broke National Education Center, Chicago, IL, http://www.goforbroke.org/learn/archives/oral_histories_videos.php?clip=28603.

${ }^{82}$ Hansen, "The 1944 Nisei Draft at Heart Mountain, Wyoming," 52.

${ }^{83}$ Chris K. Iijima, "Reparations and the 'Model Minority' Ideology of Acquiescence: The Necessity to Refuse the Return to Original Humiliation," Boston College Third World Law Journal 19, no.1 (Dec. 1998): 399.

${ }^{84}$ Ishida, interview.

${ }^{85}$ Izui, interview.

${ }^{86}$ Jimmy Konno, interview by Robery Horsting, May 3, 2003, Tape 2, Hanashi Oral History Archives, Go For Broke National Education Center, New York City, NY, http://www.goforbroke.org/learn/archives/oral_histories_videos.php?clip=34502.

${ }^{87}$ Stanley Hayami, 26 June 1943, Stanley Hayami Diary 1941-1944, Online Archive of California.

${ }^{88}$ Izui, interview.

${ }^{89}$ Yasunori Deguchi, interview by Russel Nakaishi, March 17, 2006, Tape 2, Hanashi Oral History Archives, Go For Broke National Education Center, Kona, HI, http://www.goforbroke.org/learn/archives/oral_histories_videos.php?clip=65002.
} 
had a deep understanding of the wrongs they had endured. Conrad Kurahara summarizes this feeling well saying: "deep down we knew what a terrible wrong it was." 90 How can one then reconcile their ultimate decision to serve in an apparently patriotic fashion with this critical political consciousness?

The interviews and diaries of volunteers from camp reveal a common awareness and fear of being without a state. This crisis motivated many to volunteer in order to claim their place in the American political community and was thus consistent with their political consciousness as it was their only viable means of protection. Though many initially responded to the draft like Mitsuo Kodama who recalls: "I was so mad, I said: 'to Hell with the United States Army, I wouldn't join you guys for nothin"” or Victor Izui who said simply and emphatically, "Up your ass, Uncle Sam!" they eventually volunteered to avert the dangers of being without a state. ${ }^{91}$ Indeed, Kodama decided to serve when confronted by his mother who told him:

You were born and raised in the United States, you only have one country and that country is America, the United States. If you went to Japan you would not be accepted as a Japanese you are a 'Gaijin,' which is a foreigner, so, therefore, you will be treated like a foreigner and you will not be accepted as a Japanese and your life will be miserable in Japan. $^{92}$

Kodama's initial hope to become part of the Japanese political community implicitly confirms the necessity of joining one of these communities in order to regain one's ability to possess rights. As other social factors would prevent his inclusion in Japan, his only option was to reclaim his American citizenship by serving in the military. Hayami expresses this same concern and realizes that it is imperative to lay claim to citizenship and the rights it entails. As he contemplated volunteering, he wrote: "now the people outside want to take our citizenship away...if they take our citizenship away from us we'll be people without a country!"93 Though Hayami did not, perhaps, realize that he already occupied a position in which his citizenship was nullified, the fear he feels at the thought of being without a country indicates that these volunteers were aware of the dangers they faced in the absence of one. Lloyd Kurihara, a volunteer from the Poston, Arizona internment camp also echoed this same sentiment saying simply: "I had no other place to go." 94 Though seemingly non-political, this statement also carries the urgency of membership in a community. These volunteers, should they desire to

\footnotetext{
${ }^{90}$ Conrad Kurahara, interview by Christine Sato, June 19, 2000, Tape 1, , Hanashi Oral History Archives, Go For Broke National Education Center, Las Vegas, NV, http://www.goforbroke.org/learn/archives/oral_histories_videos.php?clip=12701.

${ }^{91}$ Mitsuo Kodama, interview by Robert Horsting, May 6, 2004, Tape 4, Hanashi Oral History Archives, Go For Broke National Education Center, Las Vegas, NV, http://www.goforbroke.org/learn/archives/oral_histories_videos.php?clip=45104; Izui, interview.

92 Kodama, interview.

${ }^{93}$ Hayami, 14 December 1942, Stanley Hayami Diary.

${ }^{94}$ Lloyd Kurihara, interview by Ian Kowata, May 19, 2001, Tape 1, Hanashi Oral History Archives, Go For Broke National Education Center, Fresno, CA, http://www.goforbroke.org/learn/archives/oral_histories_videos.php?clip=17601.
} 
ensure their safety and that of their community, had to make a claim to political inclusion, yet it was their very exclusion which foreclosed the possibility of doing so through rights claims. Having been reduced to a body lacking political significance, it was only through the physical body that a viable challenge to their political alienation was possible.

This fear of statelessness and the urgency of regaining of political community could only be achieved by the sacrifice of the pure, biological body. These volunteers often indicate that they did not think in terms of rights questions at the time of their internment. When asked if he thought in terms of constitutional rights, Thomas Kaihara, whose father was interned at Tule Lake, replied: "not at that time." 95 Similarly, Izui's mother convinced him to serve and "kept stressing...duty more than rights." 96 Simply because they did not think in terms of rights, though, did not mean that their actions were apolitical. Indeed, having established that the extra-legal nature of internment entailed the inability to lay claim to rights in the first place, claiming rights as a form of resistance would be futile and ineffective. In the absence of legal rights and the ability to challenge for them, the only way to lay claim to the political community which could then grant them these rights was by risking and sacrificing their lives on the battlefield. Kaihara said: "if I got killed in combat, at least my brother can say: 'look, my brother gave his life for his country.' They can walk up the street with their heads high." 97 This is not merely a claim of pride for Kaihara's brother, but rather indicates that the sacrifice of his life would gain his family inclusion in the

American political community as they could once again walk its streets with dignity. The actions of these volunteers, then, represented a thoroughly political statement in that it represented the re-integration of human biological existence into a community.

\section{Conclusion}

The Japanese Americans who fought for the United States went on to become the most decorated troops of the war in the $442^{\text {nd }}$ and the $100^{\text {th }}$ infantry battalion..$^{98}$ Through their bravery, they earned their inclusion in the American body politic. This achievement was most famously recognized by President Truman who remarked "you fought not only the enemy, but you fought prejudice - and you have won." 99 This story of success, however, has often been used to support a myth which holds that Asian Americans "did not make waves, overcame prejudice, and turned into good solid middle-class citizens." 100 The story of Japanese-American volunteers has become a paradigmatic case which has been mobilized to argue that success is possible even in the most

\footnotetext{
${ }^{95}$ Kaihara, interview.

${ }^{96}$ Izui, interview.

${ }^{97}$ Kaihara, interview.

${ }^{98}$ Eric J. Sundquist, “The Japanese-American Internment: A Reappraisal,” The American Scholar 57, no. 4 (Fall 1988): 545.

${ }^{99}$ Harry S. Truman, "Remarks Upon Presenting a Citation to a Nisei Regiment," July 15, 1946, Public Papers of the Presidents, Harry S. Truman, https://www.trumanlibrary.gov/publicpapers/index.php?pid=1666\&st=\&st1=.

${ }^{100}$ David Mura, New England Review 15, no. 3 (Summer 1993), 145.
} 
oppressive conditions when people are not so concerned with political claims and work harder to overcome them. A 1949 article about the post-war race relations of Japanese American and white soldiers hints at this argument. To the author, interaction between these soldiers at a football game demonstrated that "if you don't run around squalling about minorities and their rights, but simply take action...very few people...will give it a second thought." ${ }^{101}$ The language of this text illustrates a somewhat demeaning tone with regard to those Japanese Americans who refused to fight because of the nullification of their rights and, more broadly, to those who attempt to create social change for disadvantaged groups. To proponents of this myth, "Asian Americans vindicate the American Dream." 102 This myth is thus used to maintain the status quo, for those who believe in it may indicate that the disadvantages which other minorities face are simply a result of their poor effort. The blame for their conditions is thus shifted away from American society and placed squarely on the shoulders of those who it disadvantages. Examining Japanese-American volunteers, then, reveals that their success was not because of a lack of focus on the political or a willing investment in the society which had deprived them. The underpinnings of myths of Asian success are called into question. Those who volunteered were not blindly obedient, unaware, or unwilling to challenge for rights; they understood that they lacked the ability to make such claims in exile from their political community in their given historical context. Perhaps one of the most common phrases used by Japanese Americans during internment gains another meaning in this context. "Shikata Ga Nai" is a Japanese phrase meaning: "it cannot be helped." Those that used this phrase did not mean their situation was helpless, but perhaps that they had little recourse other than to do whatever was necessary to rejoin the American community. The dangers they faced without this community were such that their ultimate sacrifice to regain their place within it truly could not be helped. One is then left to contemplate how it is that such a sacrifice was necessary and realize that this was not triumph, but tragedy.

\footnotetext{
${ }^{101}$ Irving C. Whittemore, “An Uncontrolled Experiment in Race Relations," The Journal of Educational Sociology 22, no. 9 (May 1949), 597.

${ }^{102}$ Frank H. Wu, Yellow: Race in America Beyond Black and White (New York: Basic Books, 2002), 44.
} 


\section{Bibliography}

Agamben, Giorgio. "Introduction to the Homo Sacer: Sovereign Power and Bare Life." In Biopolitics: A Reader. Edited by Timothy Campbell and Adam Sitze. Durham: Duke UP, 2013.

Allen, Holly. "The Citizen-Soldier and the Citizen-Internee: Fraternity, Race, and American Nationhood, 1942-46." In Forgotten Men and Fallen Women: The Cultural Politics of New Deal Narratives. Ithaca: Cornell University Press, 2015.

Arendt, Hannah. The Origins of Totalitarianism. San Diego: Harcourt Brace Jovanovich, 1973.

Arendt, Hannah. “The Perplexities of the Rights of Man.” In Biopolitics: A Reader. Edited by Timothy Campbell and Adam Sitze. Durham: Duke UP, 2013.

Aristotle. Politics. In The Basic Works of Aristotle. Edited by Richard McKeon. Translated by W.D. Ross. New York: The Modern Library, 2001.

Cicero. Pro Milone. Translated by N.H. Watts, Cambridge: Harvard University Press, 1953.

Cole, David. "Judging the Next Emergency: Judicial Review and Individual Rights in Times of Crisis.” The Michigan Law Review Association 101, no. 8 (August, 2003): 2565-2595.

Commission on Wartime Relocation and Internment of Civilians. Personal Justice Denied: Report of the Commission on Wartime Relocation and Internment of Civilians. Washington D.C.: Civil Liberties Public Education Fund, 1997.

Egami, Hatsuye. The Evacuation Diary of Hatsuye Egami. Translated by James Sakoda. Pasadena: Intentional Publications, 1996.

Fallon Jr., Richard H., and Daniel J. Meltzer. "Habeas Corpus Jurisdiction, Substantive Rights, and the War on Terror.” Harvard Law Review 120, no. 8 (June 2007): 2029-2112.

Fenno, Mary. "Forced to Leave: WWII Detention of Alaskan Japanese Americans and Aleuts." In University of Alaska Museum. Edited by Dean Kohlhoff and Terry P. Dickey. Fairbanks: University of Alaska Museum, 1997.

Fenwick, Ben. “'Stop Repeating History': Plan to Keep Migrant Children at Former Internment Camp Draws Outrage." The New York Times, June 22, 2019. Accessed November 7 , 2019. https://www.nytimes.com/2019/06/22/us/fort-sill-protests-japaneseinternment.html.

Ghachem, Malick W. “The Slave's Two Bodies: The Life of an American Legal Fiction, William and Mary Quarterly 60, no. 4 (Oct. 2003): 809-842.

Gorfinkel, Claire. Introduction to The Evacuation Diary of Hatsuye Egami, by Hatsuye Egami. Translated by James Sakoda, 9-15. Pasadena: Intentional Productions, 1996. 
Hansen, Arthur A. "The 1944 Nisei Draft at Heart Mountain, Wyoming: Its Relationship to the Historical Representation of the World War II Japanese American Evacuation." OAH Magazine of History 10, no. 4 (Summer, 1996): 48-60.

Hirabayashi v. United States, 320 U.S. 81 (1943).

Hutchinson, Dennis J. "'The Achilles Heel' of the Constitution: Justice Jackson and the Japanese Exclusion Cases." The Supreme Court Review 2002, (2002): 455-494.

Iijima, Chris K. "Reparations and the 'Model Minority' Ideology of Acquiescence: The Necessity to Refuse the Return to Original Humiliation." Boston College Third World Law Journal 19, no.1 (Dec. 1998): 385-427.

Irons, Peter. Justice at War. Oxford: Oxford University Press, 1983.

Iwamura, Jane Naomi. "Critical Faith: Japanese Americans and the Birth of a New Civil Religion.” American Quarterly 59, no. 3 (September, 2007): 937-968.

Jackson, Robert H. "Wartime Security and Liberty Under Law." 2007 James McCormick Mitchell Lecture. Delivered at Buffalo Law School, Buffalo, NY, May 9, 1951.

Japanese American Citizens League as Amicus Curiae Supporting Respondents at Donald J. Trump, President of the United States v. International Refugee Assistance Project, No. 16-1436 (U.S. June 2, 2017) and at Donald J. Trump, President of the United States v. State of Hawaii, No. 16-1540 (U.S. June 26, 2017) [hereinafter Brief for the United States].

Jefferson, Thomas. "The Declaration of Independence." Historic American Documents 1776. Accessed December 13, 2019. https://etc.usf.edu/lit2go/133/historic-americandocuments/4957/the- declaration-of-independence/.

Katyal, Neal. "Confession of Error: The Solicitor General's Mistakes During the JapaneseAmerican Internment Cases" [blog]. United States Department of Justice. May 20, 2011, accessed November 7, 2019. https://www.justice.gov/archives/opa/blog/confessionerror- solicitor-generals-mistakes-during-japanese-american-internment-cases.

Korematsu v. United States, 323 U. S. 214 (1944).

Korematsu v. United States, 582 F. Supp. 1406 (N.D. Cal. 1984).

LegiSchool Project, The Japanese-American Internment during WWII: A Discussion of Civil Liberties Then and Now. Sacramento: Senate Publications, 2000.

Ludington, Sarah H. "The Dogs that Did Not Bark: The Silence of the Legal Academy During World War II.” Journal of Legal Education 60, no. 3 (February 2011): 396-432.

McLemore, Henry. "This Is War! Stop Worrying About Hurting Jap Feelings." Seattle Times, January 30, 1942. Accessed November 9, 2019. http://densho.org/wpcontent/uploads/2016/06/Documents_SPW.pdf. 
Mura, David. "Re-X-Amining Japanese Americans.” New England Review 15, no. 3 (Summer1993): 143-165.

Ngai, Mae M. Impossible Subjects: Illegal Aliens and the Making of Modern America. Princeton: Princeton University Press, 2004.

Rundle, Kristen. "Legal Subjects and Juridical Persons: Developing Public Legal Theory through Fuller and Arendt." Netherlands Journal of Legal Philosophy 3, (2014): 212-239.

Savage, Charlie. "Korematsu, Notorious Supreme Court Ruling on Japanese Internment, Is Finally Tossed Out." The New York Times. June 26, 2018. Accessed November 16, 2019. https://www.nytimes.com/2018/06/26/us/korematsu-supreme-courtruling.html.

Scherini, Rose D. "When Italian Americans Were 'Enemy Aliens." In Una Storia Segreta: The Secret History of Italian American Evacuation and Internment During World War II. Edited by Lawrence DiStasi. Berkeley: Heyday Books, 2001.

Spickard, Paul R. "The Nisei Assume Power: The Japanese Citizens League 1941-1942." Pacific Historical Review 52, no. 2 (May 1983): 147-174. Starkey, Marion L. The Cherokee Nation. New York: Alfred A. Knopf, 1946.

Sundquist, Eric J. “The Japanese-American Internment: A Reappraisal.” The American Scholar 57, no. 4 (Fall 1988): 529-547.

Truman, Harry S. "Remarks Upon Presenting a Citation to a Nisei Regiment." July 15, 1946, Public Papers of the Presidents, Harry S. Truman. https://www.trumanlibrary.gov/publicpapers/index.php?pid=1666\&st=\&st 1=.

Trump v. Hawaii, 585 U. S. __ (2018).

United States Department of the Navy, Japanese Question, Report On by Kenneth D. Ringle. Lieutenant Commander United States Navy, Los Angeles, California 1941.

United States Department of War, United States Fourth Army. Final Report: Japanese Evacuation from the West Coast 1942, by John Lesesne DeWitt. U.S. Western Defense Command and Fourth Army, San Francisco, California 1943.

Whittemore, Irving C. "An Uncontrolled Experiment in Race Relations." The Journal of Educational Sociology 22, no. 9 (May 1949): 590-597.

Wu, Frank H. Yellow: Race in America Beyond Black and White. New York: Basic Books, 2002.

78 Cong. Rec. S1, 739-40. April 13, 1943. Voluntary testimony of Lt. General DeWitt before the House Naval Affairs Subcommittee to Investigate Congested Areas. https://babel.hathitrust.org/cgi/pt?id=umn.31951d03671272h\&view=1up\& seq=5. 